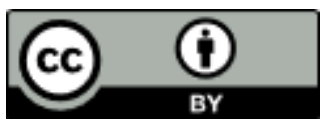

UDC 811.111'373.72=111

811.163.6'373.72=111

Original scientific article

Received on 03.09. 2018

Accepted for publication on 20.03. 2019

https://doi.org/10.29162/jez.2019.3

\title{
Gašper Ilc
}

Frančiška Lipovšek

University of Ljubljana

\section{Images of scales: \\ An English-Slovenian contrastive analysis of idiomatic minimizers and maximizers*}

The paper investigates the syntactic, semantic, and cultural properties of minimizers and maximizers from a contrastive perspective. Minimizers and maximizers are scalar constructions whose function is to strengthen the speaker's (negative) assertion by pointing to the minimal (minimizers) or the maximal (maximizers) point on a pragmatic scale. The syntactic analysis reveals that these items are predominantly sub-clausal (V+NP/PP or NP/PP), and polarity sensitive, requiring the presence of a polarity licenser. The lexical analysis identifies three possibilities with regard to lexical selections in the two languages: a complete, partial, and a non-existent lexico-semantic overlap. Furthermore, the corpus data indicate that there is considerable variation in the lexical items appearing in minimizers and maximizers (e.g., give a damn/shit/toss/fuck/monkey's/fig/rat's (arse, ass, fart)/hoot). Even though minimizers and maximizers in both languages involve the metaphor MORE IS UP, LESS IS DOWN / GOOD IS UP, BAD IS DOWN and PART-FOR-WHOLE metonymy, the analysis shows that the lexical selection in the two languages diverges due to different cultural conceptualisations and cultural background. The observation and results of the analysis presented herein aim at contributing to a better understanding of idiomatic expressions from the viewpoint of contrastive linguistics, cultural studies, and cultural conceptualisation.

Key words: cognitive semantics; contrastive analysis; cultural conceptualisation; minimizers; maximizers; polarity.

\footnotetext{
* We would like to thank the editors and the two anonymous reviewers for their helpful and insightful comments, which helped improve the paper.
} 


\section{Gašper Ilc - Frančiška Lipovšek: Images of scales: An English-Slovenian contrastive analysis of idiomatic minimizers and maximizers}

\section{Introduction}

Minimizers and maximizers are quantificational/scalar lexical items with reference to the minimal and maximal scalar degree (Bolinger 1972; Israel 1996; 2001; 2011; Horn 2001; Hoeksema \& Rullmann 2001; Postal 2004). Coined by Bolinger (1972) in his ground-breaking work on quantificational elements, the term MINIMIZERS pertains to lexical items which describe the minimal amount or quantity on a given or implied scale. Under the scope of negation, this minimal amount is negated, resulting in the interpretation of the absence of even the smallest amount possible. Thus, in (1a) a sound is a very small quantity of noise, and by negating even this small quantity, the sentence is interpreted as involving a silent situation.

(1) a. Now is the moment. Don't make a sound. ${ }^{1}$

b. She also said that when my tooth catches fire again, which it will, I won't be able to save it for love or money.

MAXIMIZERS (cf. Israel 2001; Hoeksema \& Rullmann 2001), on the other hand, are the opposite of minimizers: they are lexical items which point to the maximal amount or quantity on a given or implied scale (1b). When negated, they give rise to the interpretation that not even the highest amount/quality could make the proposition come true. The semantic/pragmatic value of minimizers/maximizers can be best explained by applying Fauconnier's (1975: 361-365) pragmatic scale analysis, as exemplified in (2): negating the minimal amount $x_{1}$ or the maximal amount $y_{\mathrm{n}}$ entails the absence of all amounts higher than $x_{1}$ on the scale (in the case of minimizers) or the absence of all amounts lower than $y_{\mathrm{n}}$ on the scale (in the case of maximizers). ${ }^{2}$

(2) a. Minimizers

high-quantity

(norm)

low-quantity

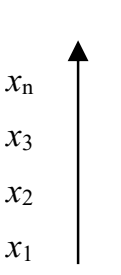

(2) b.

$\begin{array}{ll}\text { Maximizers } & \\ \text { high-quantity } & y_{\mathrm{n}} \\ \text { (norm) } & y_{\mathrm{n}-1} \\ & y_{\mathrm{n}-2} \\ \text { low-quantity } & y_{1}\end{array}$

\footnotetext{
${ }^{1}$ Unless stated otherwise, our English examples have been taken from the British National Corpus (BNC) and the British Web corpus ( $\mathrm{ukWaC}$ ), and our Slovenian examples from the Slovenian reference corpus (FidaPLUS v2).

${ }^{2}$ For a detailed application of Fauconnier's (1975) pragmatic scale analysis to minimizers and maximizers (in English) see Israel $(1996 ; 2001 ; 2011)$ and references cited therein.
} 
Standardly, minimizers/maximizers have been analysed from the perspective of negative polarity items (henceforth: NPIs) as they typically co-occur with negation. The problem of polarity licensing has been addressed by a host of researchers, who treat the phenomenon of NPIs either from the syntactic (Klima 1964; Linebarger 1987; Laka 1990; Progovac 1994; Haegeman 1995) or the semantic/pragmatic perspective (Ladusaw 1980; Heim 1984; Krifka 1990; Kadmon \& Landman 1993; Yoshimura 1994; Atlas 1996; Zwarts 1995; 1998; Israel 1996; 2001; 2011; van der Wouden 1997; Giannakidou 1998; 2002; 2006; Horn 2001; Gajewski 2007; 2011). Less attention, however, has been paid to the questions of structural relations and lexical selections in idiomatic minimizers/maximizers in these formal approaches to NPIs. Hoeksema \& Rullmann (2001: 134), following the traditional Saussurean view on arbitrariness, make two important observations about the conventionality of such expressions. First, they argue that the minimal amount in minimizers is determined conventionally, and may not reflect the minimal amount in reality. They cite the expression not spend $X$ as an example, where $X$ can stand for a cent, a nickle, or a dime. Even though a dime is the minimal amount of the three, the use of any of the three low amounts will trigger the same minimal interpretation. Translating this observation into the cognitive framework, which is adopted in this paper, we interpret this as the direct result of PART-FOR-WHOLE metonymy: amount X stands for any higher amount. Secondly, for many idiomatic minimizers/maximizers (e.g., a hill of beans), Hoeksema \& Rullmann (2001: 134) also point out that minimizers/maximizers may be conventionalized in one language but not the other. Building on a contemporary cognitive approach, Israel (2011: 98-103) goes beyond the seeming arbitrariness and analyses minimizers/maximizers in terms of their argument structure. For minimizers of the V+NP type, he shows that they typically involve a patient (e.g., hurt a fly), a theme (e.g., lift a finger), or some sort of increment (e.g., drink a drop). The author (2011: 98) argues that these arguments "are somehow affected by the action of the verb", but "are low in the thematic hierarchy, near the bottom of the action chain" in the sense of Langacker $(1987$; 1991). On the contrary, for maximizers Israel (2011: 98-99) establishes that they involve entities high in the thematic hierarchy, typically involving a causer (e.g., wild horses wouldn't drag ...), a stimulus (e.g., for all the tea in China), or an instrument (e.g., with a ten foot pole). Furthermore, recent developments in the fields of cognitive semantics (Kövecses 2005; Sharifian 2011, etc.), phraseology (Kržišnik 2008; Stopar 2015, etc.) and lexicography (Szerszunowicz 2008; Vrbinc \& Vrbinc 2014, etc.) have all shown that one of the important factors for the full/correct interpretation of idiomatic expressions 


\section{Gašper Ilc - Frančiška Lipovšek: Images of scales: An English-Slovenian contrastive analysis of idiomatic minimizers and maximizers}

is also the cultural factor - idiomatic expressions stem from the same cultural background, and reflect the conceptualisation of the same cultural group, or as Sharifian (2011:3) puts it:

[h] uman conceptualisation is as much a cultural as it is an individual phenomenon. Members of a cultural group constantly negotiate 'templates' for their thought and behaviour in exchanging their conceptual experiences. Often, complex cognitive systems emerge out of somehow concerted conceptualisations that develop among the members of a cultural group over time. Such conceptualisations give rise to the notion of cultural cognition.

In line with the presented theoretical tenets, the present paper analyses minimizers/maximizers from a contrastive English-Slovenian perspective. In order to contribute to our cross-linguistic and cross-cultural understanding of minimizers/maximizers, we focus in particular on the following research questions:

RQ1: What are the structural similarities and differences of minimizers/maximizers in the two languages?

RQ2: Which lexical items and which semantic fields are selected to denote the minimal/maximal amount in the two languages?

The analysis presented herein adopts the basic postulates of the Cognitive Grammar approach (Langacker 1987; 1991; 1993; 1999; Lakoff 1987; Kövecses 1999; 2005; 2010; Sharifian 2011, etc.). In particular, it will be assumed that language use is motivated and shaped by our cognitive processing. Some concepts result directly from our perception of reality, our physical (e.g., body movement) and social (e.g., cultural) experience, whereas others are linked with the basic ones through metaphor, metonymy, and mental imagery. In view of the fact that metaphors can be universal or culture-specific (Kövecses 2005; Sharifian 2011), and that they vary in their degree of conventionality ${ }^{3}$ (Kövecses 2010: 33-36), the present contrastive study will examine to what extent the metaphors and metonymies employed in idiomatic minimizers/maximizers are universal/culture specific and conventional. The analysis builds on Lakoff's (1987: 447-453) original claim that the meanings of idiomatic expressions are not purely arbitrary (in the Saussurean sense), but are conventionally motivated and explainable: the link between the literal meaning and the figurative meaning of an idiom is established through metaphor mapping, the conventional image, and its accompanying knowledge.

Idioms pose a problem for componential models of grammar because these models perceive the meaning of a complex grammatical unit as the sum of the

\footnotetext{
${ }^{3}$ The term here pertains to how deeply rooted a given metaphor is in a linguistic community.
} 
meanings of its constituents on the basis of grammatical rules and regular semantic principles (Fillmore et al. 1988: 502-503). A formal syntactic approach may not account for the meaning of an idiomatic expression, which is "something a language user could fail to know while knowing everything else in the language" (Fillmore et al. 1988: 504). Idiomatic expressions convey semantic and pragmatic meanings that do not correspond to compositionally derived ones. Resisting compositional analysis to a considerable extent, idioms are more easily accommodated within the framework of construction grammar, which treats constructions as symbolic pairings of form and meaning such that the link between a syntactic element and the corresponding semantic component is internal to the construction (Lakoff 1987; Langacker 1987; Fillmore et al. 1988; Goldberg 1995). There is no strict division between the lexicon and syntax, or between semantics and pragmatics; constructions are arranged in a taxonomic network and are related through schematicity (Lakoff 1987: 462-474; Goldberg 1995: 7, 73-81). For example, the constructions not spend a cent and not spend a nickle are both instances of the construction not spend $a(n)$ NOUNMIN, which, in turn, is an instance of the highly schematic construction not VERB a(n) NOUNMIN. Crucially, the meaning of the schematic idiom not VERB a(n) NOUNMIN is inherited by all taxonomically subordinate constructions (i.e. also by not hurt a(n) NOUNMIN, not lift a finger, etc.). A construction grammar-based analysis of minimizers/maximizers is beyond the scope of this paper, but it can nevertheless be proposed that idiomatic expressions involving minimizers/maximizers are lexically filled instances of schematic, formal idioms, i.e. "syntactic patterns dedicated to semantic and pragmatic purposes not knowable from their form alone" (Fillmore et al. 1988: 505). Their meanings do not arise from their syntactic structure alone, but are based on entailment relations involving a vertical scale. ${ }^{4}$ For example, 'not a minimal point on the scale' entails 'not any other point on the scale'. This entailment is part of the meaning of the schematic idiom (not VERB a(n) NOUNMIN) and is shared by all lexically filled subordinates.

\section{Methodology}

For the purposes of the analysis, idiomatic minimizers and maximizers were manually extracted from two specialised monolingual dictionaries. For English, the $O x$ ford Idioms Dictionary for learners was used, and the Slovenian data was selected from Slovar slovenskih frazemov. In line with previous research on minimizers and maximizers, the preliminary analysis has shown that English minimizers typically

\footnotetext{
${ }^{4} \mathrm{Cf}$. the discussion of let alone by Fillmore et al. (1988: 510-534).
} 


\section{Gašper Ilc - Frančiška Lipovšek: Images of scales: An English-Slovenian contrastive analysis of idiomatic minimizers and maximizers}

follow the syntactic pattern of a lexical verb followed by the singular countable NP $(\mathrm{V}+\mathrm{NP})$, whereas the patterns of maximizers are less predictable. In Slovenian, minimizers and maximizers are more easily identifiable as they generally contain the negative emphatic particle niti 'not-even'.

Building on the two observed properties, additional instances of minimizers and maximizers were extracted from relevant corpora using the Sketch Engine tool. The conventional status of a combination was determined by applying the Collocation candidate tool, which explores the context around the node, and makes the list of most frequent words that can potentially be treated as collocation candidates. Sketch Engine provides three measurements when listing collocation candidates: tscore, MI-score, and logDice. As reported by Gablasova et al. (2017: 169), of the three possibilities, the t-score is the least reliable as it is heavily dependent on corpus size, whereas the MI-score and logDice values are not affected by corpus size, and display a relative high correlation between them. In the present study, the logDice value was used throughout, because its results are easily interpretable: in theory, the $\log$ Dice values range from 0 to 14 , but are usually below 10 , with the value of 7 and above highly indicative of strong collocational association (Rychlý 2008). To provide a practical example of such an extraction, Table 1 shows collocation candidates for the combination "not give a" with $\log$ Dice values of 7 and above. Five of these candidates (damn, toss, shit, monkey's and hoot) have already been included in the Oxford Idioms Dictionary for learners, whereas four of them (rat's (arse, ass, fart), fuck, fig and sod) have not.

Table 1: Collocation candidates for the combination "not give a"

\begin{tabular}{|l|r|r|}
\hline \multicolumn{1}{|c|}{ corpus } & \multicolumn{1}{c|}{ BNC } & ukWaC \\
\hline & logDice & logDice \\
\hline damn & 11.008 & 9.947 \\
\hline toss & 9.721 & 9.389 \\
\hline shit & 9.429 & 9.032 \\
\hline rat's (arse, ass, fart) & 8.873 & 7.094 \\
\hline monkey's & 8.642 & 7.580 \\
\hline fuck & 8.551 & 8.791 \\
\hline fig & 8.091 & 7.860 \\
\hline hoot & 7.920 & 8.156 \\
\hline sod & 6.916 & \\
\hline
\end{tabular}




\section{Minimizers and maximizers in English}

\subsection{Syntactic properties ${ }^{5}$}

As pointed out by Israel (2011: 98), the most typical syntactic pattern observed in minimizers is the transitive pattern with a lexical verb followed by an indefinite singular countable noun (V+NP) as in lift a finger, bat an eye, turn a hair, believe a word, sleep a wink, hurt a fly, move a muscle, hear a word. There is some variation, for instance, the verbal complement can also be realised by a definite noun (have the faintest/foggiest idea), by a plural indefinite noun (know beans about sth) or by a quantified nominal (care/give two hoots). The verbal element can also be elided in elliptical constructions, for example, compare the full-fledged structure in (3a) with the elliptical clause in (3b).

(3) a. If you value your job, you won't breathe a word to him.

b. But my brother is coming. Not a word to him.

In addition to the prevailing $\mathrm{V}+\mathrm{NP}$ syntactic pattern, the analysis has identified two additional syntactic possibilities. The first involves the copular verb followed by an adjective (be worth a damn/farthing/penny/fig, be worth the paper it's printed/written on), and the other comprises of NPs only as in a word, a thing, a dime, a sound, a dry eye in the house, a hair out of place, room to swing a cat. Some of these minimizers i.e., NP-only minimizers, have a corresponding V+NP form, for instance $a$ word $\rightarrow$ say a word, a dime $\rightarrow$ have a dime; others, such as room to swing a cat, do not. Furthermore, an V+NP minimizer (e.g., (not) have a care in the world) can be reduced to a prepositional structure (without a care in the world).

In contrast to minimizers, maximizers are prevailingly realised by prepositional phrases (cf. Israel 2011: 98): by any stretch of imagination, by a long shot/chalk, for love or money, beyond/in your wildest dreams, in a month of Sundays, for the life of me, on your nelly, for all the tea in China, in all my born days, with a tenfoot pole/bargepole. However, we were also able to identify other patterns such as $\mathrm{V}+\mathrm{Adj}$ (be caught/seen dead), V+NP (have a (snowball's) chance/hope in hell), and NP-only maximizers (wild horses as in wild horses wouldn't drag ...).

The syntactic analysis has also revealed that while minimizers are closely incorporated into the clausal structure and linearly follow the negative word (4a), some maximizers are not fully integrated into the clausal structure, but rather function as the speaker's comments or evaluations of the proposition $(4 b-c)$. In addition, they

\footnotetext{
${ }^{5}$ The following abbreviations are used: NP - nominal phrase; AdjP - adjectival phrase; V - verb; $\mathrm{PP}$ - prepositional phrase.
} 
can also be found in the pre-negator position (4d), a position unavailable for minimizers.

(4) a. There's not a dry eye in the house as Mr Punch and a startled Toby perform 'Auld Lang Syne'.

b. If you intend me to infer that she was pregnant, then for the life of me I can see no reason why you don't actually say so.

c. 'What?' I thought, 'Not on your nelly!'

d. Wild horses wouldn't keep him away.

\subsection{Lexical and semantic properties}

Starting with the V+NP minimizers, we can first observe that while the syntactic frame is fixed, both the V and NP positions can be filled with different lexical items. To exemplify, consider the combination bat an eye. According to the dictionary entries and the corpus data, the $\mathrm{V}$ position can be filled with either the verb to bat or the verb to blink, and the NP position with noun eye or eyelid. Mutatis mutandis, the meanings of all possible combinations are synonymous, but the frequency/collocation rates show that some combinations are more frequent and conventionalized than others. The statistical data provided in Table 2 show that the most conventionalised form of the minimizer is bat an eyelid.

In (5), we provide some additional examples of most typical combinations, starting with the variation in the $\mathrm{V}$ position (5a), to be followed by the variation in the NP position (5b). The variants are arranged according to the logDice value in the descending order.

(5) a. lift/raise a finger, bat/blink an eyelid, budge/move/give an inch, breathe/utter/say/speak a word, have got/have a clue, have got/have the faintest/foggiest, give/care a damn, give/care/matter a fig, give/care/matter two hoots, hurt/harm a fly

b. hear a word/sound/peep, care a damn/jot/fig/hoot/toss/two hoots/straw/rap/tuppence, bat an eyelid/eye, move a muscle/inch, give a damn/shit/toss/fuck/monkey's/fig/rat's (arse, ass, fart)/two hoots/a hoot

Similarly, the mimimizer be worth $X$ allows different singular countable nominals for its complement, for example, be worth a penny/dime/farthing/shit/bean/pence, and one definite nominal the candle, which is, in fact, a reduced form of the idiom the game is not worth the candle. 


\section{EZIKOSLOVLJE}

20.1 (2019): 63-84

Table 2. The logDice values for the minimizer bat/blink an eye/eyelid

\begin{tabular}{|l|r|r|}
\hline \multicolumn{1}{|c|}{ minimizer } & \multicolumn{1}{|c|}{$\begin{array}{c}\text { BNC } \\
\operatorname{logDice}\end{array}$} & \multicolumn{2}{c|}{$\begin{array}{c}\mathrm{ukWaC} \\
\operatorname{logDice}\end{array}$} \\
\hline bat an eye & \multicolumn{1}{c|}{$/ /$} & 3.513 \\
\hline bat an eyelid & 9.533 & 8.333 \\
\hline blink an eye & 4.076 & 4.278 \\
\hline blink an eyelid & 6.341 & 6.399 \\
\hline
\end{tabular}

a For the query "bat" and "blink", separately; collocation candidates; attribute: word in the range from 0 to 2 .

Maximizers, on the other hand, allow fewer variations, though some have been identified. For instance, the V+NP maximizer have a (snowball's) chance in hell contains the optional nominal element in the possessive case snowball's, which is interchangeable with iceberg's, snowflake's, and cat's. In addition, the NP chance can be replaced with hope. In the case of PP maximizers, two modifications are possible. First, the maximizers by a long shot and with a ten-foot pole can have a different nominal - chalk and bargepole, respectively. Second, the maximizer in your wildest dreams also surfaces with the preposition beyond.

A question may arise at this point as to what contributes to the observed high level of variability in the case of minimizers. We assume that minimizers, typically building on PART-FOR-WHOLE metonymy, display greater variation in the selection of lexical items than maximizers because the conceptualizaton of entities in terms of parts is cognitively so fundamental that it forms a variety of categories whose linguistic manifestations can function as minimizers. But since every entity can, in principle, be part of some larger entity, it is often difficult to conceptualize the ultimate (upper) point on a scale. For this reason, maximizers typically involve grammatical elements or structures that highlight the interpretation of the ultimate point. For instance, the use of the universal quantifier and the nominal modification in the maximizer for all the tea in China or the superlative form in in your wildest dreams. We see this as a possible explanation for the low variability of maximizers. Examining lexical items featured in minimizers, we can observe that in addition to referring to small quantity, they also pertain to entities that have little or no value, and are, therefore, considered inferior and dispensable. They come from different semantic domains, the most frequent being money (a dime, a penny), body parts and effluvia (a finger, a hair, a shit), language ( $a$ word, a sound), animal world ( $a$ fly, monkey's), plants (a bean, beans), everyday objects (the paper, candle), measurement (an inch). Some of these expressions are also vulgar/offensive (rat's arse, a shit, a damn). Conversely, the items featured in maximizers reference large quantities and pertain to entities that are desirable and are perceived as positive. The 


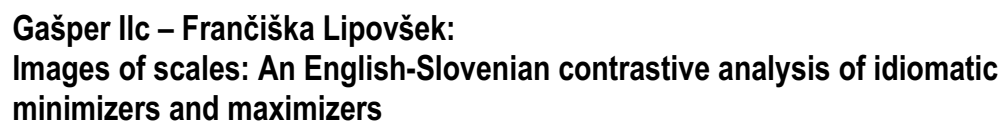

semantic domains for maximizers are similar to those of minimizers and include money (money), human activities (dreams, imagination), animals (horses), time periods (days, life, month), objects (ten-foot pole, snowball's), and goods (tea).

\section{Minimizers and maximizers in Slovenian}

\subsection{Syntactic properties}

The most distinctive element of Slovenian minimizers (6a) is the presence of the emphatic negative particle niti ('not-even'). The use of the particle niti is not obligatory. However, it seems that a miminizer with niti is much more conventionalized than the same minimizer without it. ${ }^{6}$ The particle niti is a negative concord item, so its wellformedness depends on the presence of the overt negator $n e$ 'not'. Its syntactic placement, however, is not restricted to the post-negator position (6a) as is the case in English, but includes the pre-negator position (6b) as well. In other, non-negative non-veridical contexts that license idiomatic minimizers, the emphatic negative particle niti is replaced by sam/sama/samo ('only'), as in (6c).

(6) a. Prisezi, da nikomurne zineš niti besedice! Swear:IMP that nobody not say:IND not.even word:DIM 'Swear you won't breathe a word to anybody.'

b. Niti besedice ni črhnila. not.even word:DIM not.is:IND blurted

'She didn't utter a word.' cf. *A word she didn't utter.

c. Če izusti eno samobesedo, je prvi v kaši. if say:IND one only word is:IND first in porridge

'If he breathes a word, then he'll be the first in trouble.'

The most typical syntactic pattern of Slovenian minimizers is the V+NP structure (ne poznati niti abecede 'not know even the alphabet', ne narediti niti koraka 'not take even one step'). Also fairly frequent is the (PP) $+\mathrm{V}+(\mathrm{PP})^{7}$ structure, as in za slan krompir ne imeti 'not have (money) for salted potatoes' and niti s prstom ne

\footnotetext{
${ }^{6}$ For instance, the queries "rekel besede" and "rekel niti besede" for the minimizer ne reči niti besede 'not say a word' yielded 23 and 64 hits, respectively.

${ }^{7}$ Slovenian displays a relatively free word order, allowing two variations of the V+PP structure (i.e., the PP either preceding or following the V). For example, the minimizer ne migniti s prstom has an almost equal distribution with regard to the position of V and PP in the corpus (205 vs. 207 occurrences for the $\mathrm{V}+\mathrm{PP}$ and $\mathrm{PP}+\mathrm{V}$, respectively).
} 
migniti 'not even move with (your) finger'. There are two possible modifications of the basic V+NP/PP pattern. First, the verbal element can be omitted, reducing the $\mathrm{V}+\mathrm{NP} / \mathrm{PP}$ miminizer to the NP (e.g., niti besedice 'not even a word') or to the PP (e.g., niti za mišjo dlako 'not even for a hair of a mouse'). Second, the NP/PP is omitted, resulting in the V-only minimizer (e.g., (niti besede) ne črhniti 'not even blurt or say/utter a word', (niti s prstom) ne migniti 'not even move (with a finger)'. The minimizers biti vreden počenega groša 'be worth a broken Groschen' and kolikor je črnega za nohtom 'as much as there is black under the nail' follow the be+AdjP pattern.

With Slovenian maximizers, three possible syntactic patterns can be observed: (i) the V+NP structure (e.g., ne bati se boga ne hudiča 'not be afraid of the God or the Devil'); (ii) the (PP)+V+(PP) structure (e.g., niti na konec pameti ne pasti 'not fall to the end of mind'); (iii) the PP structure (e.g., za nič na svetu 'for nothing in the world', ob svetem nikoli 'at St. never'). The last possibility is by far the most prevalent and can be extended to the V+PP pattern.

\subsection{Lexical and semantic properties}

As is the case with English minimizers, Slovenian minimizers follow a strict syntactic pattern but allow for some lexical variation. For instance, in the dominant $\mathrm{V}+\mathrm{NP}$ pattern, the V and NP slots can be filled with different lexical items. To illustrate, consider the minimizer ne reči niti besede. According to the dictionary and the corpus data, the V position can be filled with the verbs reči 'say' and črhniti 'blurt or say/utter a word', ${ }^{8}$ and the NP position with the word beseda 'word' or its diminutive besedica. All of these combinations display high collocation values (Table 3), but the combinations with the diminutive form besedica prevail. This suggests that the selection of the diminutive emphasises the minimal amount of the minimizer.

Some additional examples of the most frequently used combinations are provided in (7); first with the variation in the $\mathrm{V}$ position (7a), followed by the variation in the NP/PP position (7b).

\footnotetext{
${ }^{8}$ These two verbs have the highest collocation values, other possibilities also include verbs spregovoriti 'start speaking', izdaviti, izustiti 'utter' and ziniti 'blurt out'.
} 


\section{Gašper Ilc - Frančiška Lipovšek: Images of scales: An English-Slovenian contrastive analysis of idiomatic minimizers and maximizers}

Table 3. logDice values for the minimizer črhniti/reči niti besedice/besede 'blurt or say/utter a word'

\begin{tabular}{|l|r|}
\multicolumn{1}{|c|}{ minimizer } & \multicolumn{1}{|c|}{$\begin{array}{c}\text { (FidaPLUS v2) } \\
\text { logDice }\end{array}$} \\
\hline črhniti niti besedice & \\
\hline črhniti niti besede & 10.737 \\
\hline reči niti besedice & 5.214 \\
\hline reči niti besede & 9.360 \\
\hline
\end{tabular}

${ }^{\text {a }}$ The $\log$ Dice value for the collocation candidates in the range from 0 to 2 words.

(7) a. ne poznati/znati niti abecede 'not know even the alphabet', dati/spraviti glasu od sebe 'not give/produce even a sound', ne popustiti/premakniti se niti za las 'not budge even for a hair', ne narediti/napraviti niti koraka 'not to make even a step'

b. ne imeti niti ficka/pare/centa/za slan krompir 'not to have even a dime/penny/cent/for salted potatoes', ne premakniti se niti za ped/milimeter/centimetre/las/mišjo dlako 'not budge even for an inch/millimetre/centimetre/hair/mouse's hair, ne zaslužiti niti za sol/slan krop 'not earn even for salt/salted boiling water, ne znati šteti niti do pet/three 'not know how to count to five/three', ne seči komu niti do kolen/gležnjev/pet 'not be to somebody's knees/ankles/heels'

Slovenian maximizers display less variation. However, there are many synonymous maximizers with an emphatically negative meaning in the sense of 'never, ever', for example za nič na svetu 'for nothing in the world', niti na konec/kraj pameti ne pade 'not fall to the end of wits', niti $v$ sanjah 'not even in dreams', ob svetem nikoli 'at St. never'.

Minimizers involve expressions referring to small quantity/measurement units (cent 'cent', milimeter 'millimetre', beseda 'word'), parts of lower limbs (peta 'heel', gleženj 'ankle', koleno 'knee'), small body parts and effluvia (noht 'nail', dlaka 'hair', prst 'finger', drek 'shit'), elementary knowledge (abeceda 'alphabet'), dispensable/inexpensive/faulty objects (sol 'salt', slan krop 'salted boiling water', krompir 'potatoes', piškav oreh 'rotten walnut'), bodily activities requiring little effort (korak 'step'), animals perceived negatively (mǐs 'mouse'). Maximizers, by contrast, involve entities that are perceived as desirable, positive, strong, forceful, or represent the ultimate limit, for instance, nominals such as bogastvo 'riches', sanje 'dreams', konec pameti 'the end of wits', voli 'oxen', palica 'stick', bog 'god', hudič 'devil', and smrt 'death'. 


\section{Synthesis}

Starting with the syntactic similarities and differences between English and Slovenian minimizers/maximizers (RQ1), the predominant syntactic pattern in both languages is sub-clausal, involving the V+NP, V+PP, NP or PP structure. The maximizers in both languages appear in the NP or PP form, whereas the prevailing patterns of the minimizers are V+NP (English and Slovenian), and (PP)+V+(PP) (Slovenian). In both languages, the verbal element can be omitted, resulting in NP or PP minimizers. While in English minimizers the verbal element is, by and large, lexically vague, delexicalised, or non-specific (for instance, give, say, and care), some Slovenian minimizers include verbs that are lexically more specific or stylistically marked, for example the verb crhniti 'to blurt or say/utter a word'. ${ }^{9}$ In such cases, the nominal element may be elided (8), giving rise to a $\mathrm{V}$ minimizer.

(8) V Nemčiji zijajovanjo, vendarse nihče ne upa črhniti. In Germany stare her but REFL nobody not dares blurt 'In Germany, they all stare at her, but nobody dares to utter a word.'

Some other syntactic dissimilarities between English and Slovenian minimizers/maximizers can be attributed to different ways of forming negative sentences, in which the majority of minimizers/maximizers are found. Slovenian, as all other Slavic languages, belongs to the negative concord languages, requiring the presence of the overt negator to license negative concord items. These items, including Slovenian minimizers/maximizers with niti 'not-even', can appear in the pre- or post-negator positions (cf. Section 4.1). In Standard English, a double negation language (cf. van der Wouden 1997; Horn 2001), NPIs have to be positioned in the post-negator position. ${ }^{10}$ While this seems to hold true for English minimizers, our analysis has identified some maximizers which can also be found in the pre-negator position (cf. Section 3.1, example 4d). Perhaps the greatest syntactic difference between the minimizers/maximizers in the two languages is the presence of the emphatic negative particle niti 'not-even' in Slovenian. While in English, adding emphatic particles to stress the minimal/maximal amount encoded in the minimizers/maximizers is possible yet atypical, in Slovenian, its usage appears to be conventionalized. This observation provides further support for the original claim by Heim (1984: 104-106), who argues that English minimizers differ from other NPIs

\footnotetext{
9 The exact meaning of the verb črhniti is untranslatable into English, because it combines the meanings of the verbs to blurt, to peep, to chirp and to mutter.

${ }^{10}$ Compare (i) and (ii) containing the non-assertive pronoun anybody:
}

(i) She did not see anybody.

(ii) *Anbody was not seen. 


\section{Gašper Ilc - Frančiška Lipovšek: Images of scales: An English-Slovenian contrastive analysis of idiomatic minimizers and maximizers}

in that they contain covert even. For Slovenian, it can thus be claimed that in contrast to English, niti 'not-even' is conventionally overt. Furthermore, Slovenian resorts to the use of synthetic diminutive forms, a feature non-existent in English minimizers. ${ }^{11}$ Thus, comparing the English minimizer not say a word and its Slovenian equivalent ne reči niti besedice, we can observe that the notion on the minimal amount is explicitly encoded in English only once; namely, with the lexical item word denoting the smallest unit of speech, whereas in Slovenian the minimalness is further highlighted by the emphatic particle niti and the diminutive.

Concerning the semantic fields of nominals in the English and Slovenian minimizers/maximizers (RQ2), we can first observe that there are many similarities despite the fact that English and Slovenian belong to different language groups. This can be attributed to the shared Greco-Roman tradition and Judeo-Christian ethics, which contributed significantly to conceptualisation in both languages. Perhaps the most illustrative example is the minimizer not lift a finger, which appears in both languages, and can be directly linked to the Bible (Matthew 23:4). The expression in a month of Sundays refers to Sabbath, the day commanded by the Scriptures to be the day for rest and worship. There are also numerous references to hell, Devil, and God, though they are more frequent in Slovenian than English. These expressions may either refer to the intense heat associated with hell (e.g., have a snowball's chance in hell), devil's fearsomeness (e.g., bati se živega vraga 'be afraid of the living devil') or the vertical positioning of hell and heaven (e.g., ne bati se ne boga ne vraga 'not be afraid of the God or the Devil'), which assumes that up is better and down is worse. The same tradition is behind the direct link between the concept of worthiness and material possession, as reflected in minimizers of the type be worth + money. The word denoting the exact amount is, however, culturedependent, with English featuring a penny, a dime, or a cent, and Slovenian making reference to Groshen, para, tolar, and cent. ${ }^{12}$ Furthermore, in both languages, the nominals featured in minimizers/maximizers come from semantic fields involving everyday objects typically of no/little value (paper, candle, salt), farming and land cultivation (walnut, potato, oxen), and the animal world (fly, monkey, mouse). What all these nominals have in common is that they all pertain to concrete objects that have been closely interwoven with the everyday life of speakers.

In sum, comparing English and Slovenian minimizers/maximizers with regard to the semantic selection of lexical items appearing in these structures, our analysis

\footnotetext{
${ }^{11}$ For a detailed contrastive analysis of English and Slovenian diminutives, cf. Sicherl $(2012 ; 2018)$.

12 groš 'Groschen' from the Austrian Empire, para 'para' a subunit for Yugoslav dinar, tolar 'tolar' a Slovenian pre-euro currency.
} 
has identified three distinct patterns. First, there is a complete lexico-semantic overlap between the two languages, as in say a word, and lift a finger. Second, in some cases, the lexical items come from the same semantic field but are lexicalized differently due to different socio-cultural backgrounds: worth a penny vs. ne biti vreden niti počenega groša 'not be worth not-even a broken Groschen' or wild horses would not ... vs. niti $z$ volmi 'not even with the oxen'. Finally, the last pattern comprises of minimizers/maximizers that involve lexical items from different semantic fields, for example have a clue and in a month of Sundays vs. their Slovenian equivalents ne poznati niti abecede 'not know even the alphabet' and ob svetem nikoli 'at St. never', respectively. Furthermore, the corpus data have revealed that there is considerable variation in the lexical items appearing in minimizers and maximizers, involving both the nominal (e.g., give a damn/shit/toss/fuck/monkey's/fig/rat's (arse, ass, fart)/hoot) and the verbal element (e.g., budge/move/give an inch). This is particularly the case with the NPs appearing in the minimizers. We attribute this to the fact that the conceptualizaton of entities in terms of parts is cognitively so fundamental that it forms a variety of categories whose linguistic manifestations can function as minimizers.

The lexico-semantic analysis also shows that minimizers involve notions of small size or quantity/low value, and that maximizers involve notions of large size or quantity/high value. This is a manifestation of the fact that minimizers/maximizers, being scalar in nature, build on the conceptual metaphor MORE IS UP, LESS IS DOWN (Johnson 1987: 121-124; Lakoff 1987: 276; Kövecses 2005: 23; Kövecses 2010: 40). In many cases the metaphor pertains to quality rather than quantity: what holds a low position is considered to be less worthy/important, and the opposite is true for the high position. For this reason, it is the conceptual metaphor GOOD IS UP, BAD IS DOWN, which is coherent with the metaphors WORTHY/IMPORTANT/HIGH STATUS IS UP, UNWORTHY/UNIMPORTANT/LOW STATUS IS DOWN (cf. Lakoff \& Johnson 1980/2003: 16-18). The Slovenian minimizer ne seči komu niti do kolen/gležnjev/pet 'not be up to somebody's knees/ankles/heels' provides a good example: all three nominals refer to lower parts of the lower extremities, and if a person is not even up to somebody's knees/ankles/heels, then they are less worthy. The English equivalent cannot hold a candle builds on the same conceptual metaphor, although taking the vertical job hierarchy perspective rather than the body position perspective. ${ }^{13}$ Of special interest is the Slovenian maximizer $n e$ bati se ne boga ne vraga 'not be afraid of the God or the Devil', which includes

${ }^{13}$ In the past, the job of the apprentice was to assist their superior by holding the candle while they were working. Since this was the least skilled work, the apprentice who couldn't even hold the candle was not even worth the lowest position (cf. https://www.phrases.org.uk/meanings/183700.html). 


\section{Gašper Ilc - Frančiška Lipovšek: Images of scales: An English-Slovenian contrastive analysis of idiomatic minimizers and maximizers}

both extreme ends of the same vertical scale devil (i.e., hell) - god (i.e., heaven), and the maximizer ne bati se ne smrti ne vraga 'not be afraid of death or the Devil', which includes the extreme ends of two different scales (i.e., hell - heaven, and death - life).

The analysed uses of minimizers/maximizers are clear manifestations of the orientational metaphor based on the UP-DOWN schema, with verticality as the source domain and quantity/quality as the target domain. The metaphorical mapping is motivated by our everyday physical experience of correlations between verticality and quantity/quality (Lakoff 1987: 275-277; Lakoff \& Johnson 1980/2003: 1618). Nevertheless, the interpretation of minimizers/maximizers relies not only on metaphor but also on metonymy. Metaphor involves mapping across distinct domains, metonymy mapping within the same domain. Metonymy is traditionally understood as a "stand for" relation (Lakoff \& Johnson 1980/2003: 36), either in terms of word meaning or in terms of category structure (Lakoff 1987: 77-79). It is also defined as a reference-point phenomenon - a means of providing mental access to a category via another category (Langacker 1993: 30; 1999: 198-202; Kövecses \& Radden 1998: 39), and a process of domain highlighting (Croft 1993: 348). Minimizers build largely on PART-FOR-WHOLE metonymy: a given quantity (size, value) stands for any possible larger quantity (larger size, higher value). For example, in the expression not say a word the minimizer stands for any possible string of words, ultimately yielding the interpretation 'remain silent'. PART-FORWHOLE metonymy is also found with maximizers, although to a lesser extent. The Slovenian expression niti na konec/kraj pameti ne pasti 'not fall to the end of wits', features an ultimate limit (konec/kraj pameti 'the end of wits') standing for the whole (i.e. pamet 'wits'). The English expression not in your wildest dreams features an extreme representative of a category (WILDEST DREAMS) standing for the whole category (DREAMS). The maximizer not with a ten-foot pole is a possible example of a WHOLE-FOR-PART metonymy: the expressed length (implying distance) stands for any possible smaller length (distance). It can be assumed that many minimizers/maximizers build on an interaction between metaphor and metonymy, which accords with the view that metaphors, including those based on the UPDOWN schema, are often metonymy-motivated (Kövecses \& Radden 1998: 61; Barcelona 2011: 39).

The selection of lexical items is, as shown above, (to some extent) culturedependent. For instance, both English and Slovenian minimizers referring to uselessness/worthlessness (e.g., be worth $X$, give a $X$ ) contain monetary units of small value; but the actual name for the unit depends on the historical backround (e.g., $a$ penny vs. a Groschen). In a like manner, the minimizer move an $X$ in English con- 
tains the imperial unit of measurement (an inch), whereas the Slovenian equivalent the metric unit (a millimetre). Another example is the culturally-specific choice of animal nouns, as featured in the maximizer wild horses would not drag ... and its Slovenian equivalent niti z volmi 'not even with the oxen'. In Slovenian culture, the concept of wild horses has not been very salient; for that reason, the conceptual mapping of wild horses onto powerfulness did not take place. However, since the Slovenian cultural heritage is more connected to farming and land cultivation than wilderness, it is not surprising that many minimizers/maximisers resort to lexical items from this semantic domain, for example, niti $z$ volmi 'not even with the oxen', za slan krompir ne imeti 'not have (money) for salted potatoes'. For centuries, a pair of oxen rather than horses was used for heavy farm work, and potatoes were a staple diet of working classes. Being part of the Austrian Empire, Slovenian culture was (and still is) strongly linked with the Roman Catholic tradition and its fear-instilling rhetoric. This can explain why there are so many Slovenian minimizers/maximizers that make reference to God, Devil, and hell. In the English Protestant tradition, references to hell do not pertain so much to fear but more to the characteristics of hell (e.g., heat). The maximizers with a ten-foot pole and niti s palico 'not even with a stick' involve physical distance. In English, but not Slovenian, the actual distance is explicitly expressed (a ten-foot pole or a bargepole), indicating that distance and maintaining personal space play a more important role in English than Slovenian culture. This is in line with Hall's (1966: 119-129) theory of personal distance, according to which contact cultures (e.g. countries of southern Europe) are characterized by keeping closer interpersonal spaces than non-contact cultures (e.g. countries of northern Europe).

\section{Conclusion}

The paper has looked into the syntactic, semantic, and cultural dimensions of idiomatic minimizers and maximizers from a contrastive English-Slovenian perspective. Starting with the synctactic properties, we have observed that in both languages these idiomatic expressions involve a sub-clausal structure, predominantly, $\mathrm{V}+\mathrm{NP}, \mathrm{V}+\mathrm{PP}$ combinations. The verbal element may be elided in both languages resulting in NP and PP minimizers/maximizers, but only in Slovenian can the nominal element be omitted, giving rise to $\mathrm{V}$ minimizers. In addition, minimizers/maximizers are polarity-sensitive; hence, they require the presence of the overt polarity licenser.

The lexical analysis of minimizers/maximizers has singled out three possibilities. First, in both languages, there is a complete lexico-semantic overlap (word and 


\section{Gašper Ilc - Frančiška Lipovšek: Images of scales: An English-Slovenian contrastive analysis of idiomatic minimizers and maximizers}

beseda). Second, the lexical items may belong to the same semantic field (e.g., money) but are culturally conditioned (e.g., penny and groš 'Groschen'). Third, the lexical items featured in minimizers/maximizers come from different semantic fields. The corpus data has also shown that there is considerable variation in the lexical items appearing in minimizers and maximizers (e.g., give a damn/shit/toss/fuck/monkey's/fig/rat's (arse, ass, fart)/hoot and budge/move/give an inch).

Minimizers/maximizers in both languages build on conceptual metaphor and metonymy. The former involves either the concept of quantity (MORE IS UP, LESS IS DOWN), or quality (GOOD IS UP, BAD IS DOWN). It is here that the cultural dimension plays an important role, for what is considered as high/small quantity or as more/less worthy/strong is not universally established, but results from different individual and cultural conceptualisations. Our analysis has identified some different cultural conceptualisations in the case of English and Slovenian minimizers/maximizers.

Last but not least, English and Slovenian minimizers/maximizers merit further research in the framework of construction grammar. It can be proposed that idiomatic expressions presented in the paper are lexically filled instances of schematic idioms whose meanings are based on entailment relations involving a vertical scale.

\section{References}

Atlas, Jay David. 1996. 'Only' noun phrases, pseudo-negative generalized quantifiers, negative polarity items, and monotonicity. Journal of Semantics 13(4). 265-328. doi: https://doi.org/10.1093/jos/13.4.265

Barcelona, Antonio. 2011. Reviewing the properties and prototype structure of metonymy. In Benczes, Réka \& Barcelona, Antonio \& Ruiz de Mendoza Ibáñez, Francisco José (eds.), Defining metonymy in cognitive linguistics: towards a consensus view, 7-58. Amsterdam: John Benjamins. doi: https://doi.org/10.1075/hcp.28

Bolinger, Dwight. 1972. Degree words. The Hague: Mouton.

Croft, William. 1993. The role of domains in the interpretation of metaphors and metonymies. Cognitive Linguistics 4(4). 335-370. doi: https://doi.org/10.1515/cogl.1993.4.4.335

Fauconnier, Gilles. 1975. Pragmatic scales and logical structure. Linguistic Inquiry 6(3). $353-375$. 


\section{EZIKOSLOVLJE \\ 20.1 (2019): 63-84}

Fillmore, Charles J. \& Kay, Paul \& O'Connor, Mary Catherine. 1988. Regularity and idiomacity in grammatical constructions: the case of LET ALONE. Language 64(3). 501538. doi: $10.2307 / 414531$

Gablasova, Dana \& Brezina, Vaclav \& McEnery, Tony. 2017. Collocations in corpusbased language learning research: identifying, comparing, and interpreting the evidence. Language Learning 67(S1). 155-179. doi: https://doi.org/10.1111/lang.12225

Gajewski, Jon R. 2007. Neg-raising and polarity. Linguistics and Philosophy 30. 289-328. doi: https://doi.org/10.1007/s10988-007-9020-z

Gajewski, Jon R. 2011. Licensing strong NPIs. Natural Language Semantics 19. 109-148. doi: https://doi.org/10.1007/s11050-010-9067-1

Giannakidou, Anastasia. 1998. Polarity sensitivity as (non)veridical dependency. Amsterdam: Benjamins. doi: https://doi.org/10.1075/la.23

Giannakidou, Anastasia. 2002. Licensing and sensitivity in polarity items: from downward entailment to (non)veridicality. Proceedings from the 38th Meeting of the Chicago Linguistic Society 38(2). 29-54. Retrieved from: http://home.uchicago.edu/ giannaki/pubs/ cls.giannakidou.pdf. Accessed: 30 March 2018.

Giannakidou, Anastasia. 2006. Only, emotive factive verbs, and the dual nature of polarity dependency. Language 82(3). 575-603. doi: 10.1353/lan.2006.0136

Goldberg, Adele. 1995. Constructions: a construction grammar approach to argument structure. Chicago: The University of Chicago Press.

Haegeman, Liliane. 1995. The syntax of negation. Cambridge: Cambridge University Press.

Hall, Edward T. 1966. The hidden dimension. New York: Doubleday.

Heim, Irene. 1984. A note on negative polarity and downward entailingness. Proceedings of North East Linguistic Society 14. 98-107.

Hoeksema, Jack \& Rullmann, Hotze. 2001. Scalarity and polarity: a study of scalar adverbs as polarity items. In Hoeksema, Jack \& Rullmann Hotze \& Sanchez-Valencia, Victor \& van der Wouden, Ton (eds.), Perspectives on negation and polarity items, 129-172. Philadelphia: John Bejamins. doi: https://doi.org/10.1075/la.40

Horn, Laurence R. 2001. A natural history of negation. Chicago: The University of Chicago Press.

Israel, Michael. 1996. Polarity sensitivity as lexical semantics. Linguistics and Philosophy 19. 619-666. doi: https://doi.org/10.1007/BF00632710

Israel, Michael. 2001. Minimizers, maximizers, and the rhetoric of scalar reasoning. Journal of Semantics 18(4). 297-331. doi: https://doi.org/10.1093/jos/18.4.297

Israel, Michael. 2011. The grammar of polarity. Pragmatics, sensitivity, and the logic of scales. Cambridge: Cambridge University Press. doi: https://doi.org/10.1017/CBO9780511975288

Johnson, Mark. 1987. The body in the mind. The bodily basis of meaning, imagination, and 


\section{Gašper Ilc - Frančiška Lipovšek: Images of scales: An English-Slovenian contrastive analysis of idiomatic minimizers and maximizers}

reason. Chicago and London: Cambridge University Press.

Kadmon, Nirit \& Landman, Fred. 1993. Any. Linguistics and Philosophy 16(4). 353-422. doi: https://doi.org/10.1007/BF00985272

Klima, Edward S. 1964. Negation in English. In Fodor, Jerry A. \& Katz, Jerrod J. (eds.), The structure of language, 246-323. Englewood Cliffs, New Jersey: Prentice-Hall.

Kövecses, Zoltán. 1999. Does metaphor reflect or consitute cultural models? In Gibbs, Raymond W. \& Steen, Gerard (eds.), Metaphor in cognitive linguistics, 167-188. Amsterdam: John Benjamins. doi: https://doi.org/10.1075/cilt.175

Kövecses, Zoltán. 2005. Metaphor in culture. Universality and variation. Cambridge: Cambridge University Press. doi: https://doi.org/10.1017/CBO9780511614408

Kövecses, Zoltán. 2010. Metaphor. A practical introduction. Oxford: Oxford University Press. doi: https://doi.org/10.1017/S0047404503254051

Kövecses, Zoltán \& Radden, Günter. 1998. Metonymy: Developing a cognitive linguistic view. Cognitive Linguistics, 9(1). 37-78. doi: https://doi.org/10.1515/cogl.1998.9.1.37

Krifka, Manfred. 1990. The semantics and pragmatics of weak and strong polarity items. Semantics and Linguistic Theory 4. 195-219. doi: http://dx.doi.org/10.3765/salt.v4i0.2462

Kržišnik, Erika. 2008. Viri za kulturološko interpretacijo frazeoloških enot. Jezik in slovstvo 53(1). 33-47.

Ladusaw, William. 1980. Polarity sensitivity as inherent scope relations. New York and London: Garland Publishing.

Laka, Miren Itziar Mugarza. 1990. Negation in syntax: on the nature of functional categories and projections. PhD dissertation. Department of Linguistics and Philosophy. MIT.

Lakoff, George. 1987. Women, fire, and dangerous things. Chicago and London: The University of Chicago Press.

Lakoff, George \& Johnson, Mark. 1980/2003. Metaphors we live by. Chicago: The University of Chicago Press. doi: 10.7208/chicago/9780226470993.001.0001

Langacker, Ronald W. 1987. Foundations of cognitive grammar: vol. I: theoretical prerequisites. Stanford, CA: Stanford University Press.

Langacker, Ronald W. 1991. Concept, image, and symbol. The cognitive basis of grammar. Berlin, New York: Mouton de Gruyter.

Langacker, Ronald W. 1993. Reference-point constructions. Cognitive Linguistics 4. 1-38. doi: https://doi.org/10.1515/cogl.1993.4.1.1

Langacker, Ronald W. 1999. Grammar and conceptualization. Berlin, New York: Mouton de Gruyter.

Linebarger, Marcia C. 1987. Negative Polarity and Grammatical Representation. Linguistics and Philosophy 10(3). 325-387. doi: https://doi.org/10.1007/BF00584131

Postal, Paul M. 2004. Sceptical linguistic essays. Oxford: Oxford University Press. 


\section{EZIKOSLOVLJE \\ 20.1 (2019): 63-84}

Progovac, Ljiljana. 1994. Negative and positive polarity. Cambridge: Cambridge University Press.

Rychlý, Pavel. 2008. A lexicographer-friendly association score. In Sojka, Petr \& Horák, Aleš (eds.), Proceedings of Recent Advances in Slavonic Natural Language Processing, RASLAN, 6-9.

Sharifian, Farzad. 2011. Cultural conceptualisations and language theoretical framework and applications. Amsterdam/Philadelphia: John Benjamins Publishing Company. doi: https://doi.org/10.1075/clscc.1

Sicherl, Eva. 2012. Slovene nominal diminutives and their English equivalents: a comparison. ELOPE: English Language Overseas Perspectives and Enquiries 9. 53-63. doi: https://doi.org/10.4312/elope.9.2.53-63

Sicherl, Eva. 2018. A comparison of diminutive expressions in English and Slovene as exemplified by Roald Dahl's Matilda. Languages in Contrast 18(2). 283-306. doi: https://doi.org/10.1075/lic.15016.sic

Stopar, Andrej. 2015. Encounters with national stereotypes in foreign language teaching: adjectives describing Americans. ELOPE: English Language Overseas Perspectives and Enquiries 12. 105-118. doi: https://doi.org/10.4312/elope.12.1.105-118

Szerszunowicz, Joanna. 2008. Decoding phraseological units as a socio-linguistic problem (on the example of onomastic Idioms). Nation and language: modern aspects of sociolinguistic development, third conference, 118-121. Kaunas: Kauno technologijos universiteto, Panevéžys Institute Centre of Languages. Retrieved from: https://www.researchgate.net/publication/291246890_Decoding_Phraseological_Units as_A_Socio-Linguistic_Problem_on_the_Example_of_Onomastic_Idioms. Accessed: 30 March 2018.

Vrbinc, Alenka \& Vrbinc, Marjeta. 2014. Phraseological units with onomastic components: the case of English and Slovene. Revista de Lingüistica Teórica y Aplicada 52(1). 133-153. doi: http://dx.doi.org/10.4067/S0718-48832014000100007

van der Wouden, Ton. 1997. Negative contexts. Collocation, polarity and multiple negation. Routledge Studies in Germanic Linguistics. London and New York: Routledge.

Yoshimura, Akiko. 1994. A cognitive constraint on negative polarity phenomena. Proceedings of the Twentieth Annual Meeting of the Berkeley Linguistics Society: General Session Dedicated to the Contributions of Charles J. Fillmore, 599-610. doi: http://dx.doi.org/10.3765/bls.v20i1.1432

Zwarts, Frans. 1995. Nonveridical contexts. Linguistic Analysis 25(3/4). 286-310.

Zwarts, Frans. 1998. Three types of polarity. In Hamm, Fritz; Hinrichs, Hinrichs W. (eds.), Plurality and quantification, 177-238. Dordrecht: Kluwer Academic Publlishers. 


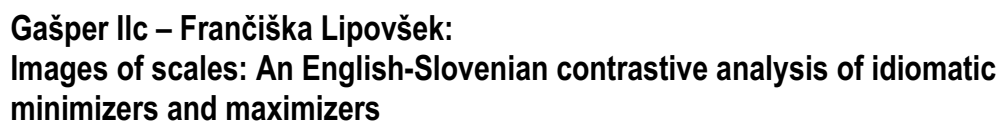

\section{Corpora and dictionaries}

$\mathrm{BNC}=$ The British National corpus. 2010. $<$ https://the.sketchengine.co.uk/ $>$

$\mathrm{UkWaC}=$ web-derived (domain .uk) corpus. $<$ https://the.sketchengine.co.uk $/>$

FidaPLUS v2 = Slovenian reference corpus. $<$ https://the.sketchengine.co.uk/ $>$

Keber, Janez (2011). Slovar slovenskih frazemov. Ljubljana: Založba ZRC, ZRC SAZU.

Oxford Idioms. Dictionary for Learners of English. 2006. Oxford: Oxford University Press.

The Phrase Finder. <https://www.phrases.org.uk/>

\section{Authors' addresses:}

University of Ljubljana, Faculty of Arts

Aškerčeva 2, 1000 Ljubljana

E-mail: Gasper.Ilc@ff.uni-lj.si

Franciska.Lipovsek@ff.uni-lj.si

\section{PREDODŽBE SKALA: ENGLESKO-SLOVENSKA KONTRASTIVNA ANALIZA IDIOMAT- SKIH MINIMIZATORA I MAKSIMIZATORA}

U radu se istražuju sintaktička, semantička i kulturna obilježja minimizatora i maksimizatora iz kontrastivne perspektive. Minimizatori i maksimizatori skalarne su konstrukcije, čija je funkcija pojačavanje govornikove (negativne) tvrdnje pokazivanjem na minimalnu (minimizatori) ili maksimalnu (maksimizatori) točku na pragmatičkoj skali. Sintaktička analiza otkriva da je većinom riječ o podrečeničnim jedinicama (GLAGOL + IMENSKA SKUPINA/PRIJEDLOŽNA SKUPINA ili IMENSKA SKUPINA/PRIJEDLOŽNA SKUPINA), koje su osjetljive na polarnost, odnosno zahtijevaju prisutnost izraza koji dopušta polarnost. Leksičkom raščlambom utvrđene su tri mogućnosti leksičkog odabira u dvama jezicima: potpuno, djelomično i nepostojeće leksičko-semantičko preklapanje. Usto, podaci dobiveni iz korpusa pokazuju da postoji značajna varijacija u leksičkim jedinicama koje se pojavljuju u minimizatorima i maksimizatorima (npr. give a damn/shit/toss/fuck/monkey's/fig/rat's (arse, ass, fart)/hoot). Iako minimizatori i maksimizatori u oba jezika uključuju metafore VIŠE JE GORE, MANJE JE DOLJE/DOBRO JE GORE, LOŠE JE DOLJE te metonimiju DIO-ZA-CJELINU, analiza pokazuje da se leksički odabir u dvama jezicima razlikuje zbog različite kulturne konceptualizacije i kulturne pozadine. Zapažanja i rezultati izneseni u ovom radu nastoje doprinijeti boljem razumijevanju idiomatskih izraza s gledišta kontrastivne lingvistike, kulturnih studija i kulturne konceptualizacije.

Ključne riječi: kognitivna semantika; kontrastivna analiza; kulturna konceptualizacija; minimizatori; maksimizatori; polarnost. 